І. В. Мельник, Т. І. Фаріон, М. О. Поліщук

ДУ “Центральний методичний кабінет з вищої медичної освіти МОЗ Украӥни”

\title{
ЗАБЕЗПЕЧЕННЯ НАВЧАЛЬНО-МЕТОДИЧНОЮ ЛІТЕРАТУРОЮ - ВИМОГА 3 ПРОВАДЖЕННЯ ОСВІТНЬОЇ ДІЯЛЬНОСТІ У СФЕРІ ВИЩОЇ ОСВІТИ ВІДПОВІДНО ДО ЛІЦЕНЗІЙНИХ УМОВ ПРОВАДЖЕННЯ ОСВІТНЬОЇ ДІЯЛЬНОСТІ ЗАКЛАДІВ ОСВІТИ
}

\author{
I. V. Melnyk, T. I. Farion, M. O. Polishchuk \\ PI "The Central Higher Medical Education Curriculum Office of Ministry of Helthcare \\ of Ukraine" \\ SUPPLY WITH COURSEWARE - THE REQUIREMENT FOR \\ EDUCATION ACTIVITIES IMPLEMENTATION IN HIGHER EDUCATION \\ ACCORDING TO LICENCE PROVISIONS OF EDUCATION ACTIVITIES \\ IMPLEMENTATION BY EDUCATIONAL INSTITUTIONS
}

\begin{abstract}
Мета роботи - провести комплексний аналіз інформації щодо забезпечення студентів усіх спеціальностей вищих навчальних закладів МОЗ України підручниками, навчальними посібниками, довідковою та іншою навчальною літературою та оцінити відповідність вимогам щодо провадження освітньої діяльності у сфері вищої освіти.

Основна частина. Комплексний аналіз інформації щодо забезпечення студентів вищих навчальних закладів МОЗ України навчальною літературою, що здійснюється Державною установою “Центральний методичний кабінет з вищої медичної освіти МОЗ України”, свідчить про те, що у 2016/2017 навчальному році загальні показники забезпеченості навчальною літературою студентів ВНЗ МОЗ України в цілому суттєво не зросли. При цьому виявлено найгірші показники щодо забезпеченості у 2016/2017 навчальному році навчальними книгами студентів спеціальності “Технологія фармацевтичних препаратів” та “Клінічна фармація”. Найвищі показники забезпеченості підручниками у 2016/2017 навчальному році студентів спеціальностей “Лікувальна справа”, “Педіатрія”, “Медико-профілактична справа” зафіксовано у Харківському національному медичному університеті; ДВНЗ “Тернопільський державний медичний університет імені І. Я. Горбачевського МОЗ України” та Запорізькому державному медичному університеті. Виявлені особливості забезпечення студентів вищих навчальних закладів МО3 країни навчальною літературою дозволяють оцінити відповідність вимогам щодо провадження освітньої діяльності у сфері вищої освіти та надати рекомендації.

Висновок. Для реалізації забезпечення навчальною книгою здобувачів вищої освіти у вищих навчальних закладах МОЗ України, що є необхідною умовою виконання навчальним закладом Ліцензійних умов провадження освітньої діяльності, необхідно створити умови для активізації профільних фахівців вищих навчальних закладів щодо написання сучасної навчально-методичної літератури, виділяти достатню кількість коштів на придбання та видання медичних книг.
\end{abstract}

Ключові слова: навчально-методична література; Ліцензійні умови провадження освітньої діяльності; вища освіта.

The aim of the study is to conduct a comprehensive analysis of the information about textbooks, manuals, reference and other educational literature supply of all students higher educational institutions of Ukraine Ministry of Healthcare of Ukraine and to assess compliance requirements for carrying out educational activities in higher education.

The main body. Comprehensive analysis of data about supply of higher educational institutions of Ministry of Healthcare of Ukraine students with educational literature carried out by Public Institution "The Central Higher Medical Education Curriculum Office of Ministry of Helthcare of Ukraine”, indicates that the 2016/2017 academic year, general indicators of university students supply with educational literature generally have not significantly increased. The worst indicators of supply with educational books in 2016/2017 academic year were found on students of specialty “Technology of pharmaceuticals” and "Clinical pharmacy”. The best supply of students of "Medicine", "Pediatrics", "Medical and preventive care" specialties with textbooks in the 2016/2017 academic year was noted in Kharkiv National Medical University; I. Horbachevsky Ternopil State Medical University and Zaporizhzhia State Medical University. The received data on supply of university students with educational literature enables the assess compliance with the requirements for carrying out educational activities in higher education and provide recommendations.

Conclusion. For the realization of supply of students of higher educational institutions of Ministry of Healthcare of Ukraine with educational textbooks, which is a prerequisite for Licence provisions of education activities implementation, it is necessary to create conditions for activization of higher educational institutions specialists for writing modern educational literature, provide sufficient funds for acquisition and publication of medical books.

Key words: courseware; Licence provisions of education activities implementation; higher education.

(c) I. В. Мельник, Т. I. Фаріон, М. О. Поліщук 
Вступ. Відповідно до Закону України “Про вищу освіту”, освітня діяльність у сфері вищої освіти провадиться вищими навчальними закладами, науковими установами (для підготовки фахівців ступеня доктора філософії) на підставі ліцензій, які видаються центральним органом виконавчої влади у сфері освіти і науки у порядку, визначеному Кабінетом Міністрів України згідно з цим законом (ст. 24, п. 1).

Діяльність вищих навчальних закладів і наукових установ, що провадиться з метою підготовки здобувачів вищої освіти на певних рівнях вищої освіти за певними спеціальностями, здійснюється відповідно до вимог щодо провадження освітньої діяльності у сфері вищої освіти, визначених у Ліцензійних умовах провадження освітньої діяльності закладів освіти (постанова Кабінету Міністрів України від 30.12.2015 року № 1187, далі - Ліцензійні умови) [1]. Відомість про інформаційне забезпечення освітньої діяльності у сфері вищої освіти містить інформацію щодо забезпечення усіх навчальних дисциплін підручниками, навчальними посібниками, довідковою та іншою навчальною літературою, із зазначенням року видання та кількості примірників (додаток 6 до Ліцензійних умов), оскільки належне забезпечення здобувачів вищої освіти навчальною літературою є обов’язковою вимогою для здійснення освітнього процесу.

Мета роботи - провести комплексний аналіз інформації щодо забезпечення студентів усіх спеціальностей вищих навчальних закладів МO3 України підручниками, навчальними посібниками, довідковою та іншою навчальною літературою та оцінити відповідність вимогам щодо провадження освітньої діяльності у сфері вищої освіти.
Основна частина. Аналіз забезпечення студентів вищих навчальних закладів МОЗ України (далі - ВНЗ МОЗ України) навчальними книгами, який щороку здійснює Державна установа "Центральний методичний кабінет з вищої медичної освіти МОЗ України” (далі - ЦМК) за даними від навчальних закладів на початку навчального року (станом на 1 вересня), свідчить про те, що у 2016/2017 навчальному році навіть “формально” загальні показники забезпеченості навчальною літературою студентів ВНЗ МОЗ України суттєво не зросли і становлять: підручниками - 31 \%, посібниками 19 \% (порівняно $з$ 2015/2016 навчальним роком: підручниками - 25 \%, посібниками - 17 \%), тоді як відповідно до нових Ліцензійних умов змінився принцип обрахунку цих показників. При цьому забезпеченість студентів медичних факультетів зі спеціальностей “Лікувальна справа”, “Педіатрія” та “Медико-профілактична справа” у 2016/2017 навчальному році, становить: підручниками - 42 \%, посібниками - 21 \% (табл. 1).

До 2014/2015 навчального року до аналізу забезпечення студентів навчально-методичною літературою були включені лише ті підручники та посібники, які отримали відповідні грифи-дозволи до видання МОН України, МОЗ України та ЦМК.

Починаючи з 2015/2016 навчального року, ураховуючи вимоги пункту першого частини першої статті 1 “Основні терміни та їх визначення” Закону України “Про вищу освіту”, при обрахунках забезпечення студентів навчальною літературою враховуються і ті книги, які видані за дозволами вчених рад ВНЗ МОЗ України та надійшли до фондів бібліотек з вересня 2014 року.

Таблиця 1. Динаміка забезпечення підручниками і посібниками студентів медичних факультетів ВНЗ МОЗ України зі спеціальностей “Лікувальна справа”, “Педіатрія” та “Медико-профілактична справа” протягом 2011-2016 років (державна мова, термін використання - 5 років)

\begin{tabular}{|c|c|c|}
\hline Рік проведення обрахунків & Забезпечення підручниками (\%) & Забезпечення посібниками (\%) \\
\hline 2011 & 28 & 27 \\
\hline 2012 & 37 & 39 \\
\hline 2013 & 35 & 30 \\
\hline 2014 & 34 & 18 \\
\hline $2015^{*}$ & 35 & 17 \\
\hline $2016^{* *}$ & 42 & 21 \\
\hline
\end{tabular}

Примітки:

1. * - враховані навчально-методичні книги, які видані за дозволами вчених рад ВНЗ МОЗ України та надійшли до фондів бібліотек з вересня 2014 року, з розрахунку: одна навчальна книга на трьох студентів, що одночасно вивчають дану дисципліну (Ліцензійні умови надання освітніх послуг у сфері вищої освіти, затверджені наказом Міністерства освіти і науки України від 24.12.2003 року № 847).

2. ** - враховані навчально-методичні книги, які видані за дозволами вчених рад ВНЗ МОЗ України та надійшли до фондів бібліотек з вересня 2014 року, з розрахунку: одна навчальна книга на п’ятьох студентів, що одночасно вивчають дану дисципліну (Ліцензійні умови провадження освітньої діяльності закладів освіти, затверджені постановою Кабінету Міністрів України від 30.12 .2015 року № 1187). 
Процедура видання навчальних книг тільки за рішеннями вчених рад навчальних закладів дуже часто “скорочує” час, витрачений авторським колективом на підготовку рукопису до його видання. Адже Комісія для організації підготовки навчальної та навчально-методичної літератури для осіб, які навчаються у вищих медичних (фармацевтичному) навчальних закладах та закладах післядипломної освіти MO3 України (утворена за наказом МОЗ України від 19.01.2015 року № 20 “Про організацію підготовки навчальної та навчально-методичної літератури” із змінами, внесеними наказом МОЗ України від 04.05.2016 року № 407, далі - Комісія), приймає рукописи на розгляд та ухвалення до видання після їх фахового рецензування, організацію якого забезпечує ЦМК. При цьому Комісія приймає лише ті рукописи навчальної літератури для вітчизняних здобувачів вищої освіти, які підготовлені українською мовою.

Разом з тим значного покращення забезпечення студентів сучасною навчальною книгою у більшості ВНЗ МОЗ України не спостерігається (таблиці 2-8).

Таблиця 2. Забезпечення підручниками та посібниками дисциплін спеціальностей “Лікувальна справа”, “Педіатрія”, “Медико-профілактична справа”

\begin{tabular}{|c|c|c|c|c|c|c|c|c|c|c|c|c|c|c|c|}
\hline \multirow[t]{3}{*}{2015} & ВH3 & $\begin{array}{c}\text { БДмУ } \\
\text { (Педіат- } \\
\text { рія) }\end{array}$ & ВНМУ & ДДМА & ЗДМУ & ІФНМУ & ЛНМУ & HМУ & ОНМУ & тДМУ & УМСА & ХНМУ & $\begin{array}{c}\text { ДНМУ } \\
\text { (без } \\
\text { грифів) }\end{array}$ & Сер.\% & \multirow{3}{*}{$\begin{array}{c}1 \\
\text { книга } \\
\text { на } \\
3-x \\
\text { студ. }\end{array}$} \\
\hline & Підруч. & 51 & 29 & 43 & 54 & 23 & 42 & 55 & 9 & 39 & 28 & 36 & 6 & 35 & \\
\hline & Посіб. & 40 & 2 & 8 & 36 & 7 & 15 & 27 & 7 & 35 & 7 & 8 & 6 & 17 & \\
\hline \multirow{3}{*}{2016} & ВH3 & $\begin{array}{c}\text { БДмУ } \\
\text { (Педіат- } \\
\text { рія) }\end{array}$ & ВНМУ & ДДМА & ЗДМУ & ІФНМУ & ЛНМУ & HМУ & ОНМУ & ТДМУ & УМСА & ХНМУ & $\begin{array}{c}\text { ЛДМУ } \\
\text { (без } \\
\text { грифів) }\end{array}$ & Сер.\% & \multirow{3}{*}{$\begin{array}{c}1 \\
\text { книга } \\
\text { на } \\
5-\mathrm{x} \\
\text { студ. }\end{array}$} \\
\hline & Підруч. & 46 & 41 & 40 & 47 & 41 & 44 & 46 & 27 & 53 & 42 & 58 & 14 & 42 & \\
\hline & Посіб. & 37 & 6 & 10 & 43 & 20 & 16 & 23 & 8 & 24 & 16 & 32 & 15 & 21 & \\
\hline
\end{tabular}

Таблиця 3. Забезпечення підручниками та посібниками дисциплін спеціальності “Стоматологія”

\begin{tabular}{|c|c|c|c|c|c|c|c|c|c|c|c|c|c|c|}
\hline \multirow{3}{*}{2015} & BH3 & БДМУ & BНMУ & ДДМА & ЗДМУ & ІФНМУ & ЛНМУ & HMУ & ОНМУ & ТДМУ & УМСА & ХНМУ & $\begin{array}{l}\text { ДНМУ } \\
\text { (без } \\
\text { грифів) }\end{array}$ & Сер.\% \\
\hline & Підруч. & 47 & 25 & 31 & 51 & 43 & 33 & 51 & 9 & 29 & 35 & 32 & 7 & 33 \\
\hline & Посіб. & 35 & 1 & 2 & 32 & 11 & 13 & 24 & 5 & 15 & 7 & 7 & 9 & 13 \\
\hline \multirow{3}{*}{2016} & ВН3 & БДМУ & BНMУ & ДДМА & ЗДМУ & ІФНМУ & ЛНМУ & HMУ & ОНМУ & ТДМУ & УМСА & ХНМУ & $\begin{array}{c}\text { ЛДМУ } \\
\text { (без } \\
\text { грифів) }\end{array}$ & Сер.\% \\
\hline & Підруч. & 63 & 51 & 46 & 66 & 61 & 66 & 57 & 40 & 69 & 64 & 73 & 16 & 56 \\
\hline & Посіб. & 49 & 2 & 4 & 47 & 25 & 17 & 27 & 18 & 37 & 21 & 20 & 19 & 24 \\
\hline
\end{tabular}

Таблиця 4. Забезпечення підручниками та посібниками дисциплін спеціальності “Фармація”

\begin{tabular}{|c|c|c|c|c|c|c|c|c|c|c|c|c|c|}
\hline \multirow{3}{*}{2015} & BH3 & ВНМУ & НФаУ & ДДМА & ЗДМУ & ІФНМУ & ЛНМУ & HMУ & ОНМУ & ТДМУ & БДМУ & $\begin{array}{c}\text { ДНМУ (без } \\
\text { грифів) }\end{array}$ & Сер.\% \\
\hline & Підруч. & 16 & 14 & 21 & 26 & 34 & 27 & 32 & 5 & 19 & 34 & 4 & 21 \\
\hline & Посіб. & 3 & 17 & 5 & 46 & 15 & 9 & 21 & 4 & 15 & 22 & 3 & 15 \\
\hline \multirow{3}{*}{2016} & ВH3 & ВНМУ & НФаУ & ДДМА & ЗДМУ & ІФНМУ & ЛНМУ & НМУ & OHМУ & ТДМУ & БДМУ & $\begin{array}{c}\text { лДМУ (без } \\
\text { грифів) }\end{array}$ & Сер.\% \\
\hline & Підруч. & 25 & 33 & 19 & 21 & 43 & 36 & 22 & 13 & 36 & 26 & 6 & 26 \\
\hline & Посіб. & 8 & 32 & - & 38 & 25 & 16 & 11 & 10 & 21 & 18 & 11 & 17 \\
\hline
\end{tabular}

Таблиця 5. Забезпечення підручниками та посібниками дисциплін спеціальності “Клінічна фармація”

\begin{tabular}{|c|c|c|c|c|c|c|c|c|}
\hline \multirow{3}{*}{2015} & ВНЗ & ВНМУ & НФаУ & ДДМА & ЛнМУ & ТДМУ & БДМУ & Сер.\% \\
\cline { 2 - 10 } & Підруч. & 17 & 12 & 19 & 22 & 19 & 32 & 20 \\
\cline { 2 - 10 } & Посіб. & 5 & 14 & 7 & 8 & 11 & 30 & 13 \\
\hline \multirow{3}{*}{2016} & ВНЗ & ВНМУ & НФаУ & ДДМА & ЛНМУ & ТДМУ & БДМУ & Сер.\% \\
\cline { 2 - 10 } & Підруч. & 24 & 24 & 16 & 30 & 28 & 21 & 24 \\
\cline { 2 - 10 } & Посіб. & 4 & 22 & - & 11 & 16 & 14 & 11 \\
\hline
\end{tabular}


Таблиця 6. Забезпечення підручниками та посібниками дисциплін спеціальності “Технологія парфумерно-косметичних засобів”

\begin{tabular}{|c|c|c|c|c|c|c|}
\hline \multirow{3}{*}{2015} & ВНЗ & НФаУ & ЗДМУ & НМУ & ТДМУ & Сер.\% \\
\cline { 2 - 7 } & Підруч. & 16 & 21 & 27 & 16 & 20 \\
\cline { 2 - 7 } & Посіб. & 13 & 41 & 19 & 13 & 22 \\
\hline \multirow{3}{*}{2016} & ВНЗ & НФаУ & ЗДМУ & НМУ & ТДМУ & Сер.\% \\
\cline { 2 - 7 } & Підруч. & 33 & 18 & 22 & 28 & 25 \\
\cline { 2 - 7 } & Посіб. & 23 & 31 & 10 & 16 & 20 \\
\hline
\end{tabular}

Таблиця 7. Забезпечення підручниками та посібниками дисциплін спеціальності “Технологія фармацевтичних препаратів”

\begin{tabular}{|c|c|c|c|}
\hline \multirow{3}{*}{2015} & ВНЗ & НФаУ & Сер.\% \\
\cline { 2 - 4 } & Підруч. & 9 & 9 \\
\cline { 2 - 4 } & Посіб. & 14 & 14 \\
\hline \multirow{3}{*}{2016} & ВНЗ & НФаУ & Сер.\% \\
\cline { 2 - 4 } & Підруч. & 16 & 16 \\
\cline { 2 - 4 } & Посіб. & 22 & 22 \\
\hline
\end{tabular}

Таблиця 8. Забезпечення підручниками та посібниками дисциплін спеціальності “Медична психологія”

\begin{tabular}{|c|c|c|c|c|c|}
\hline \multirow{2}{*}{2015} & ВНЗ & БДМУ & ВНМУ & НМУ & Сер.\% \\
\cline { 2 - 6 } & Підруч. & 34 & 30 & 47 & 37 \\
\cline { 2 - 6 } & Посіб. & 31 & 5 & 29 & 22 \\
\hline \multirow{3}{*}{2016} & ВНЗ & БДМУ & ВНМУ & НМУ & Сер.\% \\
\cline { 2 - 6 } & Підруч. & 25 & 29 & 32 & 29 \\
\cline { 2 - 6 } & Посіб. & 22 & 3 & 19 & 15 \\
\hline
\end{tabular}

При цьому найбільш суттєво зросли показники забезпечення підручниками і посібниками сту- дентів стоматологічних факультетів. Найгірші показники забезпеченості у 2016/2017 навчальному році навчальними книгами студентів спеціальності “Технологія фармацевтичних препаратів”: підручниками - 16 \%, посібниками - 22 \% (у 2015/2016 навчальному році: підручниками - 9 \%, посібниками - 14 \%) та спеціальності “Клінічна фармація”: підручниками - 24 \%, посібниками - 11 \% (у 2015/2016 навчальному році: підручниками - 20 \%, посібниками - 13 \%).

Найвищі показники забезпеченості підручниками у 2016/2017 навчальному році студентів спеціальностей “Лікувальна справа”, “Педіатрія”, “Медико-профілактична справа” у: Харківському національному медичному університеті (58 \%); ДВНЗ “Тернопільський державний медичний університет імені I. Я. Горбачевського МОЗ України” (53 \%); Запорізькому державному медичному університеті (47 \%); спеціальності “Стоматологія”: Харківському національному медичному університеті (73 \%) та ДВН3 “Тернопільський державний медичний університет імені І. Я. Горбачевського MO3 України” (69%); спеціальності “Фармація”: ДВНЗ “Івано-Франківський національний медичний університет” (43 \%); Львівському національному медичному університеті імені Данила Галицького (36 \%); ДВНЗ “Тернопільський державний медичний університет імені І. Я. Горбачевського МОЗ України” (36 \%).

Таблиця 9. Кількість електронних видань, які надійшли до фондів бібліотек ВНЗ МОЗ України протягом 20122016 років (станом на 01.09.2016 року)

\begin{tabular}{|c|c|c|c|c|c|c|c|c|c|}
\hline \multirow{3}{*}{$\begin{array}{c}\text { ВНЗ } \\
\text { МОЗ } \\
\text { України }\end{array}$} & \multirow{3}{*}{$\begin{array}{c}\text { Кількість } \\
\text { електронних } \\
\text { видань }\end{array}$} & \multicolumn{8}{|c|}{3 них: } \\
\hline & & \multicolumn{2}{|c|}{$\begin{array}{c}\text { з дозволами МОН, МОЗ } \\
\text { України, ЦМК, вчених рад } \\
\text { ВНЗ }\end{array}$} & \multirow{2}{*}{$\begin{array}{c}\text { кількість } \\
\text { видань, } \\
\text { авторами } \\
\text { яких є фахівці } \\
\text { навч. закладу }\end{array}$} & \multirow{2}{*}{$\begin{array}{c}\text { кількість } \\
\text { видань, які } \\
\text { надійшли } \\
\text { з дозволу } \\
\text { авторів }\end{array}$} & \multirow{2}{*}{$\begin{array}{c}\text { кількість } \\
\text { видань, які } \\
\text { отримано } \\
\text { з вільних } \\
\text { джерел }\end{array}$} & \multirow[t]{2}{*}{ укр. } & \multirow[t]{2}{*}{ poc. } & \multirow[t]{2}{*}{$\begin{array}{l}\text { іншими } \\
\text { мовами }\end{array}$} \\
\hline & & підручники & посібники & & & & & & \\
\hline БДМУ & 15 & 2 & 3 & 12 & 12 & 3 & 14 & & 1 \\
\hline ВНМУ & 86 & & & & 6 & 80 & 62 & 12 & 12 \\
\hline ДМА & 43 & 5 & 38 & 42 & 1 & & 32 & 7 & 4 \\
\hline ЗДМУ & 2100 & 18 & 350 & 2030 & 2100 & & 1585 & 157 & 358 \\
\hline ІФНМУ & 131 & 31 & 100 & 94 & 12 & 25 & 107 & 14 & 10 \\
\hline ЛНМУ & 5 & 1 & 4 & 4 & 3 & 2 & 4 & & 1 \\
\hline НМУ & 79 & 39 & 23 & 1 & 78 & 1 & 21 & 47 & 11 \\
\hline НФУ & 386 & 31 & 123 & 386 & 386 & & 224 & 89 & 73 \\
\hline ОНМУ & 1005 & 101 & 148 & 44 & 9 & 952 & 239 & 443 & 323 \\
\hline ТДМУ & 564 & & 564 & 564 & 564 & & 344 & 111 & 109 \\
\hline УМСА & 667 & 6 & 53 & 560 & 604 & 63 & 256 & 231 & 180 \\
\hline ХНМУ & 724 & 10 & 57 & 700 & 724 & & 319 & 240 & 165 \\
\hline лДМУ & 194 & 10 & 57 & 3 & 3 & 191 & 63 & 124 & 7 \\
\hline Всього: & 5999 & 254 & 1520 & 4440 & 4502 & 1317 & 3270 & 1475 & 1254 \\
\hline $\begin{array}{c}\text { Всього у } \\
\text { 2011-2015: }\end{array}$ & 6143 & 407 & 1330 & 3969 & 2992 & 1922 & 2986 & 1780 & 1372 \\
\hline
\end{tabular}


Найбільша кількість електронних видань, які надійшли до фондів бібліотек ВНЗ МОЗ України протягом 2012-2016 років (табл. 9), у: Запорізькому державному медичному університеті (2100); Одеському національному медичному університеті (1005) та Харківському національному медичному університеті (724). При цьому найбільша кількість електронних видань, авторами яких $€$ фахівці навчального закладу, у: Запорізькому державному медичному університеті (2030); Харківському національному медичному університеті (700) та ДВНЗ “Тернопільський державний медичний університет імені І. Я. Горбачевського МОЗ України” (564).

Протягом останніх років “традиційно” найменш забезпеченими сучасною навчальною літературою є дисципліни блоку гуманітарної та соціально-економічної підготовки (табл. 10).

Таблиця 10. Забезпечення підручниками та посібниками по блоках дисциплін (спеціальності “Лікувальна справа”, “Педіатрія”, “Медико-профілактична справа”)

\begin{tabular}{|c|c|c|c|c|c|}
\hline & 2012 & 2013 & 2014 & 2015 & 2016 \\
\hline \multicolumn{6}{|c|}{ Гуманітарні та соціально-економічні дисципліни } \\
\hline Підручники, \% & 32 & 20 & 19 & 27 & 27 \\
\hline Посібники, \% & 44 & 30 & 23 & 14 & 9 \\
\hline \multicolumn{6}{|c|}{ Природничо-наукові дисципліни } \\
\hline Підручники, \% & 42 & 29 & 30 & 35 & 42 \\
\hline Посібники, \% & 42 & 24 & 16 & 15 & 22 \\
\hline \multicolumn{6}{|c|}{ Професійно-орієнтовані дисципліни } \\
\hline Підручники, \% & 40 & 39 & 36 & 36 & 43 \\
\hline Посібники, \% & 34 & 31 & 18 & 17 & 21 \\
\hline
\end{tabular}

Необхідно зауважити, що суттєвих відмінностей у переліку дисциплін гуманітарного блоку у навчальних планах додипломної підготовки фахівців другого (магістерського) рівня вищої освіти галузі знань 22 “Охорона здоров’я” та додипломної підготовки фахівців освітньо-кваліфікаційного рівня “Спеціаліст” галузі знань 1201 “Медицина” немає.

Найменш забезпеченими підручниками та посібниками у 2016/2017 навчальному році визначено дисципліни “Українська мова (за професійним спрямуванням)” (3 \% підручниками та 31 \% посібниками) та “Історія української культури” (0 \% підручниками та 0 \% посібниками). Враховуючи зазначені показники, а також на виконання доручення Міністерства освіти і науки України (лист “Щодо застосування державної мови” від 07.10.2016 року) протягом 2016 - I кварталу 2017 років Комісією ухвалено до видання:

- “Українська мова (за професійним спрямуванням)” (підручник, за редакцією професора С. М. Луцак - ДВНЗ “Івано-Франківський національний медичний університет”, Національний медичний університет імені О. О. Богомольця, Вінницький національний медичний університет імені M. I. Пирогова, ВДНЗ “Буковинський державний медичний університет”, Запорізький державний медичний університет, Львівський національний медичний університет імені Данила Галицького,
ДВНЗ “Тернопільський державний медичний університет імені І. Я. Горбачевського МОЗ України”); - “Українська мова в медицині” (навчальний посібник українською мовою, автори: Т. О. Лещенко, Т. В. Шарбенко, В. Г. Юфименко - ВДНЗ України “Українська медична стоматологічна академія”);

- “Діловодство та ділове мовлення в системі охорони здоров’я” (навчальний посібник, автори В. I. Крупеня та Н. В. Просоленко - Харківська медична академія післядипломної освіти);

- “Українська мова: граматика і лексика” (навчальний посібник українською, англійською та арабською мовами, автор А. В. Аністратенко ВДНЗ “Буковинський державний медичний університет”);

- “Історія української культури” (навчальний посібник, автори: А. А. Мойсей, А. В. Ткач, І. О. Скакун - ВДНЗ “Буковинський державний медичний університет”).

Із дисциплін природничої підготовки найменш забезпечені навчально-методичною літературою “Медична біологія” (8 \% підручниками та 37 \% посібниками) та “Медична інформатика” (0 \% підручниками та 25 \% посібниками). Із блоку дисциплін професійної підготовки студентів спеціальностей “Лікувальна справа”, “Педіатрія”, “Медико-профілактична справа” найменше забезпечені: “Сестринська практика” (14 \% підручниками та 12 \% посібниками); “Хірургія” (21 \% підручниками та 
22 \% посібниками); “Оториноларингологія” (0 \% підручниками та 0 \% посібниками); “Офтальмологія” (17 \% підручниками та 24 \% посібниками); “Медична психологія” (17 \% підручниками та 0 \% посібниками); “Дерматологія, венерологія” (28 \% підручниками та 0 \% посібниками); “Клінічна фармакологія” (0 \% підручниками та 12 \% посібниками); “Медична генетика” (0 \% підручниками та 0 \% посібниками); “Анестезіологія та інтенсивна терапія” (0 \% підручниками та 13 \% посібниками).

3 метою покращення забезпечення здобувачів вищої освіти професійною книгою Комісією надано дозволів на видання навчальної літератури медичного та фармацевтичного спрямування для ВНЗ МОЗ України: у 2015 році - 140, у 2016 році - 193, у І кварталі 2017 року - 39.

Разом з тим надзвичайно низькою є активність авторських колективів з числа фахівців ВНЗ МОЗ України щодо підготовки електронних підручників та посібників з урахуванням методичних рекомендацій “Підготовка електронних видань, дидактичних демонстраційних матеріалів, електронних навчальних посібників та підручників у вищих медичних навчальних закладах”, які затверджені МОЗ України 17.09.2015 року та надіслані до ВНЗ МОЗ України для впровадження з листом від 18.09.2015 року № 23-01-9/443 [2], а також методичних рекомендацій “Підготовка електронних навчальних ма- теріалів (електронних підручників та навчальних посібників) до видання”, розроблених фахівцями Національної медичної академії післядипломної освіти імені П. Л. Шупика спільно з МОЗ України та ЦМК (лист МОЗ України від 27.10.2015 року № 08.01-47/34048) [3].

Належне забезпечення студентів навчально-методичною літературою можливе лише за умови виділення достатніх коштів на закупівлю та видання сучасних підручників, посібників тощо [4].

Як свідчать дані, отримані на запит Кабінету від вищих навчальних закладів, найбільша кількість коштів на закупівлю навчальної літератури у 2016 році була спрямована у: Запорізькому державному медичному університеті (2 708 990,00 грн); ДВН3 “Тернопільський державний медичний університет імені I. Я. Горбачевського МОЗ України” (2 119 569,63 грн); Харківському національному медичному університеті (1 937 347,22 грн) (табл. 11).

При цьому із розрахунку на 1 студента найбільше коштів на закупівлю літератури українською мовою винайдено керівництвом ДВНЗ “Тернопільський державний медичний університет імені I. Я. Горбачевського МОЗ України” (472,73 грн), російською - ДЗ “Дніпропетровська медична академія МОЗ України” (703,86 грн), іноземною - Запорізького державного медичного університету (1329,43 грн) (табл. 12).

Таблиця 11. Дані про кошти, спрямовані ВНЗ МОЗ України на закупівлю навчальної літератури протягом 2013-2016 рр. (грн)

\begin{tabular}{|c|c|c|c|c|}
\hline Назва ВНЗ & 2013 р. & 2014 p. & 2015 p. & $2016 \mathrm{p.}$ \\
\hline БДМУ & 215127,40 & 439438,50 & 640930,00 & 639680,15 \\
\hline ВНМУ & 653140,00 & 682064,00 & 956828,00 & 1013353,24 \\
\hline ДМА & 755970,00 & 824200,00 & 1215540,00 & 1571250,00 \\
\hline ЗДМУ & 426890,00 & 293600,00 & 2692704,00 & 2708990,00 \\
\hline ІФНМУ & 361029,73 & 297417,17 & 685386,13 & 1036591,04 \\
\hline ЛНМУ & 351555,00 & 458550,00 & 539476,27 & 907932,00 \\
\hline НМУ & не надано & 331260,00 & 738375,00 & 72500,00 \\
\hline НФУ & 686851,00 & 300611,00 & 566688,85 & 305656,50 \\
\hline ОНМУ & 198500,00 & 392327,00 & 140077,00 & 821439,00 \\
\hline ТДМУ & 57742,00 & 193510,00 & 503178,90 & 2119569,63 \\
\hline УМСА & 343189,00 & 479520,00 & 278170,00 & 582379,00 \\
\hline ХНМУ & 768166,00 & 277580,00 & 794653,50 & 1937347,22 \\
\hline
\end{tabular}

Таблиця 12. Кошти на закупівлю навчальної літератури (на одного студента) у 2013-2016 рр. (грн)

\begin{tabular}{|c|c|c|c|c|c|c|c|c|c|c|c|c|}
\hline \multirow{2}{*}{ BH3 } & \multicolumn{4}{|c|}{ Українською } & \multicolumn{4}{|c|}{ Російською } & \multicolumn{4}{|c|}{ Іноземною } \\
\hline & 2013 & 2014 & 2015 & 2016 & 2013 & 2014 & 2015 & 2016 & 2013 & 2014 & 2015 & 2016 \\
\hline 1 & 2 & 3 & 4 & 5 & 6 & 7 & 8 & 9 & 10 & 11 & 12 & 13 \\
\hline БДМУ & 46,00 & 89,80 & 136,00 & 124,00 & - & - & - & 0,20 & 55,00 & 83,60 & 52,00 & 80,00 \\
\hline ВНМУ & 100,95 & 75,80 & 107,30 & 102,08 & 45,45 & 75,41 & 105,80 & 191,21 & 54,01 & 98,65 & 70,00 & 146,80 \\
\hline ДМА & 159,00 & 168,28 & 162,56 & 210,78 & 169,16 & 149,38 & 524,59 & 703,86 & 70,98 & 86,31 & 298,50 & 370,95 \\
\hline
\end{tabular}


Продовження табл. 12

\begin{tabular}{|c|c|c|c|c|c|c|c|c|c|c|c|c|}
\hline 1 & 2 & 3 & 4 & 5 & 6 & 7 & 8 & 9 & 10 & 11 & 12 & 13 \\
\hline ЗДМУ & 71,50 & 39,40 & 90,52 & 129,63 & 171,4 & 86,90 & 280,64 & 396,00 & 54,66 & 58,60 & 1951,94 & 1329,43 \\
\hline ІФНМУ & 64,26 & 51,35 & 52,10 & 164,35 & 155,51 & 53,11 & 69,53 & 342,48 & 56,87 & 49,71 & 25,83 & 121,78 \\
\hline ЛНМУ & 68,50 & 88,00 & 112,49 & 135,08 & 87,00 & 18,00 & - & - & 100,87 & 82,00 & 36,53 & 271,22 \\
\hline НМУ & не надано & 12,66 & 31,97 & 1,30 & не надано & 137,49 & 17,11 & 73,35 & не надано & 120,48 & 18,09 & 8,86 \\
\hline НФУ & 61,85 & 34,46 & 53.35 & 30,76 & 27,02 & 23,41 & 89,80 & 145,79 & 309,85 & 10,81 & 69,91 & 1,57 \\
\hline ОНМУ & 45,10 & 58,00 & 4,40 & 137,00 & - & 110,00 & 147,00 & 75,00 & - & 20,00 & - & 6,00 \\
\hline ТДМУ & 13,16 & 53,44 & 147,45 & 472,73 & 32,82 & 105,00 & 12,62 & - & 18,70 & 19,48 & 16,09 & 405,82 \\
\hline УМСА & 79,70 & 84,07 & 57,13 & 86,60 & 61,03 & 266,65 & 48,53 & 224,10 & 190,38 & 74,53 & 119,39 & 224,20 \\
\hline ХНМУ & 143,64 & 29,39 & 121,53 & 146,36 & 70,05 & 72,78 & 153,91 & 204,48 & 98,47 & 38,59 & 54,67 & 416,19 \\
\hline
\end{tabular}

Найбільше коштів на видання навчальної літератури у 2016 році залучено у: Національному фармацевтичному університеті (1 181 429,00 грн), ДВНЗ “Тернопільський державний медичний уні- верситет імені І. Я. Горбачевського МОЗ України” (1 135 947,23 грн) та Запорізькому державному медичному університеті (467 419,69грн) (табл. 13).

Таблиця 13. Дані про кошти, спрямовані ВНЗ МОЗ України на видання навчальної літератури у $2013-2016$ рр.

\begin{tabular}{|c|c|c|c|c|c|c|c|c|c|c|}
\hline \multirow[b]{2}{*}{ Назва ВНЗ } & \multirow{2}{*}{$\begin{array}{c}2013 \text { р. } \\
\text { загальна } \\
\text { сума } \\
\text { (грн) }\end{array}$} & \multirow{2}{*}{$\begin{array}{c}2014 \text { р. } \\
\text { загальна } \\
\text { сума } \\
\text { (грн) }\end{array}$} & \multicolumn{4}{|c|}{2015 p. } & \multicolumn{4}{|c|}{2016 p. } \\
\hline & & & $\begin{array}{c}\text { загальна } \\
\text { сума } \\
\text { (грн) }\end{array}$ & $\begin{array}{c}\text { укр. } \\
\text { мовою } \\
\text { (\%) }\end{array}$ & $\begin{array}{c}\text { рос. } \\
\text { мовою } \\
(\%)\end{array}$ & $\begin{array}{c}\text { іноз. } \\
\text { мовою } \\
(\%)\end{array}$ & $\begin{array}{c}\text { загальна } \\
\text { сума } \\
\text { (грн) }\end{array}$ & $\begin{array}{l}\text { укр. } \\
\text { мовою } \\
\text { (\%) }\end{array}$ & $\begin{array}{c}\text { рос. } \\
\text { мовою } \\
(\%)\end{array}$ & $\begin{array}{c}\text { іноз. } \\
\text { мовою } \\
(\%)\end{array}$ \\
\hline БДМУ & 25000,00 & 22775,00 & 12790,00 & 90,0 & - & 10,0 & 27910,00 & 64,2 & - & 35,8 \\
\hline ВНМУ & 96535,14 & 85142,00 & 74 508,00 & 68,2 & 18,2 & 13,6 & 294220,00 & 69,0 & 13,0 & 18,0 \\
\hline ДМА & - & - & - & - & - & - & - & - & - & - \\
\hline ЗДМУ & 296902,00 & 392 150,00 & 436000,00 & 87,0 & 10,0 & 3,0 & 467419,69 & 90,0 & 8,0 & 2,0 \\
\hline ІФНМУ & 70534,80 & 387 726,13 & 257597,00 & 90,0 & 1,0 & 9,0 & 240940,00 & 90,0 & 1,0 & 9,0 \\
\hline ЛНМУ & 151 166,00 & 174680,00 & 115227,28 & 72,9 & - & 27,2 & 353406,00 & 92,3 & - & 7,8 \\
\hline HMУ & не надано & 331260,00 & - & - & - & - & 72500,00 & 20,0 & 68,0 & 12,0 \\
\hline НФУ & 579021,00 & 202222,00 & 772213,00 & 67,3 & 28,1 & 4,6 & 1181429,00 & 62,2 & 31,5 & 6,3 \\
\hline OHMУ & 263940,17 & 272848,17 & 234549,70 & 73,1 & 26,9 & - & 336575,55 & 84,8 & - & 15,2 \\
\hline ТДМУ & 434003,00 & 519697,29 & 1214063,1 & 88,6 & 4,4 & 7,0 & 1135947,23 & 90,4 & - & 9,6 \\
\hline УМСA & 100300,00 & 145700,00 & 170300,00 & 86,0 & 8,9 & 5,1 & 150200,00 & 87,0 & 8,0 & 5,0 \\
\hline ХНМУ & 91 197,00 & 56 458,30 & 45866,40 & 54,3 & 34,1 & 11,6 & 124771,75 & 24,8 & 70,0 & 5,3 \\
\hline ДНМУ & 249346,00 & & 58314,00 & - & 100,0 & - & & & & \\
\hline
\end{tabular}

Висновок. Належне забезпечення навчальною книгою здобувачів вищої освіти у вищих навчальних закладах МОЗ України є необхідною умовою виконання навчальним закладом Ліцензійних умов провадження освітньої діяльності закладів освіти.

\section{Список літератури}

1. Ліцензійні умови провадження освітньої діяльності закладів освіти : Постанова Кабінету Міністрів України від 30.12.2015 року № 1187.

2. Підготовка електронних видань, дидактичних демонстраційних матеріалів, електронних навчальних посібників та підручників у вищих медичних навчальних закладах : методичні рекомендації, затверджені МОЗ України 17.09.2015 року.

3. Підготовка електронних навчальних матеріалів (електронних підручників та навчальних посібників) до
Реалізація зазначеного можлива за умови активізації профільних фахівців вищих навчальних закладів щодо написання сучасної навчально-методичної літератури, а також виділення достатньої кількості коштів на придбання та видання медичних книг.

видання : методичні рекомендації (лист МОЗ України від 27.10.2015 року № 08.01-47/34048).

4. Належне забезпечення вищої освіти навчальною книгою - невід'ємна складова забезпечення якості освітньої діяльності / Ю. С. П’ятницький, Н. О. Олексіна, Р. А. Стецюк [та ін.] // Актуальні питання якості медичної освіти : матеріали XIII Всеукр. наук.-практ. конф. 3 міжнар. участю. - Тернопіль : Укрмедкнига, 2016. - C. 30-37. 


\section{References}

1. Litsenziini umovy provadzhennia osvitnoi diialnosti zakladiv osvity: Postanova Kabinetu Ministriv Ukrainy vid 30.12.2015 roku № 1187 [Licence provisions of education activities implementation by educational institutions: Order of the Cabinet of Ministers of Ukraine of December 30, 2015, № 1187] [in Ukrainian].

2. Pidhotovka elektronnykh vydan, dydaktychnykh demonstratsiinykh materialiv, elektronnykh navchalnykh posibnykiv ta pidruchnykiv u vyshchykh medychnykh navchalnykh zakladakh : metodychni rekomendatsii, zatverdzheni MOZ Ukrainy 17.09.2015 roku [Electronic publications, didactic demonstrative materials, electronic textbooks preparation at higher medical educational institutions: guidelines approved by Ministry of Healthcare of Ukraine, September 17, 2015] [in Ukrainian].

3. Pidhotovka elektronnykh navchalnykh materialiv (elektronnykh pidruchnykiv ta navchalnykh posibnykiv) do vydannia : metodychni rekomendatsii (lyst MOZ Ukrainy vid 27.10.2015 roku № 08.01-47/34048) [Electronic educational materials (electronic textbooks) preparation to publication: guidelines (Order of Ministry of Healthcare of Ukraine of October 27, 2015 № 08.01-47/34048] [in Ukrainian].

4. Piatnytskyi, Yu.S., Oleksina, N.O., \& Stetsiuk, R.A. (2016). Nalezhne zabezpechennia vyshchoi osvity navchalnoiu knyhoiu - nevidiemna skladova zabezpechennia yakosti osvitnoi diialnosti [Adequate supply of higher education with academic books - an integral part of ensuring educational activities quality]. Aktualni pytannia yakosti medychnoi osvity: materialy XIII Vseukr. nauk.-prakt. konf. z mizhnar. uchastiu - Current issues of medical education quality: proceedings of XIII All-Ukrainian Scientific and Practical Conference with International Participation (pp. 30-37). Ternopil: Ukrmedknyha [in Ukrainian].

Отримано 07.04.17

Електронна адреса для листування: cmkvmo@ukr.net 